\title{
FACTORS AFFECTING INTEREST RATE AND ITS RELATION WITH BANKS' PROFITABILITY
}

\author{
Barzan Omar Ali \\ Ministry of education \\ Erbil-Kurdistan
}

\begin{abstract}
The aim of this study is to investigate the factors influencing interest rates and its relationship with private banks profitability in Erbil. The research was conducted at private banks in Erbil. The researcher attempted to find out the most of significance factor that affects interest rates and its relationship with banks Profitability. However, the researcher gathered data from employees at different level of management at private banks in Erbil. The researcher distributed 300 questionnaires, but only 238 questionnaires were received from employees and been completed. The researcher used a quantitative research method to find out the most of significance factor that affects interest rates and its relationship with banks Profitability. The findings of multiple regression analysis revealed that the highest value was for economic growth, the $\mathrm{B}$ value $=.812$, this indicates that economic growth significantly and positively effects interest rates as a result maximize bank's Profitability.
\end{abstract}

Keywords: interest rate, profitability, banks, Erbil, Kurdistan

\section{Introduction}

The impacts of worldwide powers on the elements of interest rates have been generally less examined. However, there are convincing motivations to attest that worldwide stuns affect cross-country government yield bends. The current credit emergency, for example, demonstrates that microfinance stuns can be significantly transmitted globally. As an outcome of monetary coordination, a sizable measure of local 
government obligation is held by nonnatives in worldwide capital markets. Therefore, positions on outside bonds are normally influenced by home microfinance conditions, and the other way around. Notwithstanding these critical adapted actualities, considers on the term structure of interest rates tend to give careful consideration to global overflows in yield bends (Perera, et al., 2018).

This paper responds to this call and explores the part of worldwide factors in the yield bends of a few industrialized nations. The utilitarian part and determinants of the loan fees in the economy were seriously examined by financial analysts for quite a while. Because of numerous parts played by loan costs in the economy and complex relations with other financial markers, loan fee carry on distinctively in various nations under different conditions. In this way, hypothetical strategies and models created and tried in, say, created nation with set up money related and acknowledge advertise for low level of expansion, may not generally be suitable when they are connected to progress, inflationary or other economy. In addition, utilizing diverse strategies and models, financial experts may achieve distinctive conclusions even in a similar nation.

Loan costs in Kurdistan locale of Iraq have remained reliably high finished a time of years. This has made the cost of acquiring restrictively high hence, antagonistically influencing the improvement of existing and new organizations; The hole that has created between loan costs offered for Treasury Bills (TBs) and base rates connected by business banks (CBs) in their loaning exercises are excessively wide. This has supported interest in TBs, particularly by CBs as opposed to giving danger money to business ventures; and, Reliably high edges requested by CBs between their base rates and the genuine charges for acquired finances additionally builds the real cost of overhauling bank credits and overdrafts. As per (Délèze \& Korkeamäki, 2018), loan costs' not just impact the cost of cash-flow to speculators yet in addition influence the general Profitability s for the cash spared. Horvath, et al., (2018) then again contends that loan fees are utilized by (CBK) to check inflation and increment monetary improvement.

This along these lines implies that, the fundamental motivation to control premium's monetary foundations charge using a credit card and stores is upheld by the way that the legislature must direct ventures and investment funds designs in an economy. Besides, specialists have set up that controlling loan fees' in an economy profoundly 
affects financial development since it straightforwardly decides the rate of funds and speculations. Vines \& Wills, (2018) contending on a similar premise held that at whatever point national bank sets high loan costs this naturally impacts the loan costs' charged by other money related establishments in light of benefit thought process behind working together.

Interest rate is an imperative instrument for various macroeconomic strategy choices all in all and fiscal arrangement specifically. It is an essential instrument in the hands of national banks for credit control. In this manner, "following loan costs and understanding their determinants have turned out to be pivotal from the perspective of money related market members and policymakers" (Jagannathan, 2018). Despite the fact that loan fee assurance is a component of market powers of interest and supply, RBI continues following and observing the rate through various measures like control of cash supply, open market activities, settling the base rate and so forth. Loan cost can be characterized as the cost of acquiring cash or the value that a borrower of assets ought to will to pay for getting cash from a moneylender or a monetary organization. It can likewise be portrayed as the expense paid to a moneylender on acquired budgetary resources (Fukuda, 2018). The loan specialist gets remuneration for previous different employments of their assets, including conceding their own particular utilization. The first sum loaned is known as the central and the level of the chief which is paid or payable over some undefined time frame is the interest rate or the coupon. As indicated by Sun, et al., (2018), loan fee like different costs is a cost paid for a product (stores) by the borrower to the bank. Past the social favorable position, microfinance has gone to the bleeding edge of venture stores and private financial specialists' exercises over the most recent couple of years (Nguyen,2018). Expanded consideration from these elements makes an open door for more powerful advancement in the territory of microfinance, yet may similarly make expanded (and maybe undue) weight on the arrival on speculation and in this manner upset the social effect of these foundations. Be that as it may, it is unsustainable and wasteful to give advances to the poor just based on awards and gifts from governments and universal associations. Foundations should themselves accomplish a harmony amongst money related and social proficiency, the purported twofold primary concern (DBL). 


\section{THEORETICAL FRAMEWORK}

\section{Interest rate}

The presence of worldwide money related markets guarantees that genuine long term loan costs tend to move together in various economies. Ostensible long term rates, notwithstanding, reflect inflationary desires in the different economies, which thus mirror the validity of household fiscal approach (Wynne \& Zhang, 2018). Connected to inflationary desires are exchange rate desires; however swapping scale developments can likewise happen for reasons detached to expansion differentials. Monetary hypothesis around there has a terrible record of expectation. The impact of short-term interest rate changes on long term rates isn't, in this manner, direct. An ascent in short-term rates can prompt, or be contemporary with, an ascent in long rates; yet in addition to a fall if the business sectors are persuaded that future inflation has been averted.

Our emphasis on loan fees is inspired by their connection to fiscal arrangement (Laubach \& Williams, 2016). As a house is a seemingly perpetual resource, the interest rate proper for relating the administration spill out of a house to its cost is apparently a long term rate. In any case, house costs likewise depend imperatively on straightforward entry to credit, which is thusly essentially influenced by the fiscal approach position. Kuttner \& Shim, (2016), for example, demonstrated that adjustments in the US government stores rate were related with changes in loaning by US banks, an impact that has turned out to be known as the bank loaning channel of money related arrangement. Financing costs, which are all the more firmly identified with the position of fiscal strategy, may accordingly be similarly as essential a "principal" at house costs as longerterm rates. In fact, we discover a shockingly vital part for loan costs as drivers of house costs, particularly outside the United States (Pan \& Zhou, 2017).

Our understanding is this mirrors a critical part for the bank loaning channel of financial arrangement, particularly in nations where securitization of home loans is less common. The low inflation time of late decades, the successful lower bound (ELB) crosswise over Europe, Japan, and the United States has been authoritative for an expansive part of the time, blocking macroeconomic execution. ELB scenes may turn out to be more successive and exorbitant later on, given that ostensible loan costs may remain 
generously beneath the standards of the most recent 50 years. When somebody applies for an advance with a settled financing cost, the rate they will get is ordinarily decided at the season of endorsement, and it doesn't change for the whole existence of the advance (Eichenbaum,2017). At the point when banks decide value focuses for their settled loan cost items, they construct them with respect to showcase rates accessible by then.

- Lenders who offer credit-based valuing will offer a scope of rates on their settled rate item, in light of financial soundness. All things considered, the better the candidate's FICO assessment is (or that of the cosigner/co-candidate), the better their odds for a lower rate.

- The market rate, then again, depends to a great extent on the length of the advance and different highlights, and can change in light of economic situations. This implies moneylenders may change the settled rates they offer to new candidates as economic situations change - buyers should survey the bank's present item offer before applying for a credit.

There are assortments of financing choices with various market rates that loan specialists may use to finance a settled loan cost item (Perera, et al., 2018). Normally the market rate depends on financing vehicles that have a comparative length as the normal existence of the advance item - for instance, if a credit item has a normal existence of 5 years, the market rate might be founded on the 4-year US Treasury Bond. Settled financing costs are quite often higher than variable rates at the time the credit is started. The genuine loan fee is dictated by various fundamental powers. Some of these are passing and have moderately short-term impact on loan fees.

These incorporate developments in oil costs, moves in money related and financial approach, and wage change (Délèze \& Korkeamäki, 2018). Different variables are more basic, and these are of more noteworthy enthusiasm to policymakers (and market analysts) since they decide the long-run genuine loan cost. Assessments of the long term rate are critical to financial policymakers when they decide the ideal sum and development structure of government obligation issuance every year.

The loan fees that we see in everyday life are quite often communicated in ostensible terms. For instance, if a financial specialist has cash in a bank account, the 
ostensible loan fee tells the speculator how much cash the bank will pay them as an arrival on their funds. The ostensible loan cost does not tell the financial specialist how much the arrival on their funds will be worth as far as genuine merchandise and enterprises (Horvath, et al., 2018). To locate this out, the financial specialist would need to modify the ostensible Profitability for their reserve funds by the sum by which they figure costs will change amid the time when their cash is held in their bank account. As it were, to decide the normal genuine financing cost, the speculator would need to subtract the normal expansion rate from the ostensible loan cost.

Loan fees are the signs that influence the diverting of assets to demanders or borrowers from providers or savers, specifically or through money related middle people. Since loan costs and time are firmly related, the articulation that "time is cash" is useful in comprehension the monetary demand supply linkage and, thusly, the assurance of financing costs (Vines \& Wills, 2018). Expect there are just two people. Each gains salary and pays charges. One individual chooses to spend not as much as her after-assessment or discretionary cash flow, while the other might want to spend more than his extra cash. The second individual can achieve his spending objective just on the off chance that he can discover a wellspring of financing, either from his own particular assets or from those of others. How about we accept that the essential financing appears as an advance straightforwardly from the primary person. Typically, such a credit would be made just if the moneylender is sensibly guaranteed of two things: one, that the sum acquired, or the important, will be reimbursed toward the finish of an endless supply of time; and two, that the aggregate sum the borrower guarantees to reimburse is more prominent than the primary, consequently repaying the loan specialist for surrendering the utilization of her cash for a measure of time (Nguyen,2018).

\section{Factors affecting interest rate}

An interest rate is the cost of getting cash. Or on the other hand, on the opposite side of the coin, it is the remuneration for the administration and danger of loaning cash (Perera, et al., 2018). In the two cases it keeps the economy moving by urging individuals to acquire, to loan and to spend. Be that as it may, winning financing costs are continually changing, and diverse kinds of credits offer distinctive loan fees. In the event that you are 
a loan specialist, a borrower or both, it's vital you comprehend the explanations behind these progressions and contrasts. There are many factors affecting interest rate in businesses, the researcher chose six of these factors to examine the current study:

\section{Exchange rate:}

A conversion scale is the cost of a country's cash as far as money. Consequently, a swapping scale has two segments, the residential cash and money, and can be cited either specifically or in a roundabout way. In an immediate citation, the cost of a unit of remote money is communicated as far as the residential cash. In a roundabout citation, the cost of a unit of residential money is communicated as far as the remote cash. Trade rates are cited in values against the US dollar (Huang, et al.,2018). Be that as it may, trade rates can likewise be cited against another countries cash, which are known as a cross money, or cross rate. Swapping scale is the cost of money. Trade rates can be either settled or gliding. Settled trade rates are chosen by national banks of a nation while skimming trade rates are chosen by the system of market request and supply. Trade rates are the measure of money you can trade for another. For instance, the dollar's conversion scale discloses to you how much a dollar is worth in cash (Byrne, et al.,2018). Components that impact swapping scale incorporate (1) loan costs, (2) expansion rate, (3) exchange adjust, (4) political steadiness, (5) inward concordance, (6) high level of straightforwardness in the direct of pioneers and directors, (7) general condition of economy, and (8) nature of administration. A conversion scale is the rate at which cash will be traded for another. It is likewise viewed as the estimation of one nation's money in connection to cash (Enders, et al., 2018). Trade rates can be settled or drifting. On the off chance that a nation settles its cash to that of another nation, the swapping scale between those two monetary forms won't change. On the off chance that a nation has a coasting swapping scale, the rate between its cash and some other money will change in accordance with economic situations. 


\section{Wage Inflation}

Wage inflation is a general increment in the cost of products that is gone before by and comes about because of an expansion in compensation (Murphy \& Rohde, 2018). To keep up corporate benefits after an expansion in compensation, bosses must build the costs they charge for the merchandise and ventures they give. The general expanded cost of merchandise and enterprises circularly affects the wage increment; in the end, as products and ventures in the market general increment, at that point higher wages will be expected to make up at the expanded costs of shopper products (Höpner \& Lutter, 2018). Furthermore, inflation is characterized as credits higher costs to higher work costs passed on to the shoppers by the makers.

Inflation, it must be stated, is a damn complex thing. You need to attempt to work out what the normal Australian family unit spends their cash on every week and afterward you need to screen those buys by campaigning distinctive stores to guarantee you get deals and value drops and also changes to things that are a similar cost yet now contain pretty much item. Also, that is the issue with inflation and typical cost for basic items - we generally center around the value rises and overlook or rebate the falls (Nucci \& Riggi, 2018). Political gatherings know this, which is the reason you will never hear a lawmaker discuss average cost for basic items other than to state how they are always rising and that individuals are feeling the squeeze. Ostensible wage development - before inflation is figured in - has drifted in the mid-3\% territory throughout the previous three years. In any case, inflation grabbed to $3.2 \%$ of every 2016 and 2017, disintegrating a significant part of the expansion (Donayre \& Panovska, 2018). Wage development would in a perfect world need to surpass $6 \%$ preceding specialists can feel the distinction, Indeed, even the apparently ruddy January employments report that indicated compensation grew $3.1 \%$ contrasted with a year sooner - the best pace since mid-2009 - had a few admonitions. In any case, normal hourly income climbed more than anticipated, pushing its year-over-year rate up to almost 2 percent, another repetitive high (Barsky, et al.,2014). Moreover, the nonfarm weeks' worth of work declined forcefully, which has negative ramifications for current quarter genuine GDP development.

Wage inflation is a focal piece of numerous monetary debates and is a major piece of Keynesian financial hypothesis. Regularly, contentions against raising wages or for 
constraining the wage energy of associations join these thoughts (Coibion \& Gorodnichenko, 2015). Note too that the expanded interest for products and ventures can stream crosswise over fringes, driving up costs in nations that don't have expanding compensation. Genuine wages will be compensation balanced for inflation, or, proportionally, compensation as far as the measure of products and enterprises that can be purchased. This term is utilized as a part of differentiation to ostensible wages or unadjusted wages. Inflation makes the relative estimation of cash fall after some time. For instance, on the off chance that you have $\$ 100$ and the cost of bread is $\$ 10$ per daydream, you can purchase 10 pieces of bread (Galí \& Monacelli, 2016). Assuming, in any case, the economy encounters fast inflation, the cost of bread may increment to $\$ 20$ per lounge. On the off chance that you had spared your unique $\$ 100$, it would now just purchase five chunks of bread at the expanded costs.

\section{Commodity prices}

A commodity is a monetary decent or administration that has full or considerable fundability: that is, the market regards cases of the great as proportional or almost so with no respect to who delivered them (Cavalcanti, et al., 2015). The commodity of price decent is ordinarily decided as a component of its market in general: entrenched physical items have effectively exchanged spot and subsidiary markets.

Commodity of prices that are related with product buying, prices can be valued on weight, or by standard unit. Prices are controlled by the open market free market activity. An item is an essential decent utilized as a part of business that is compatible with different commodity of a similar kind; commodities are frequently utilized as contributions to the generation of different merchandise or administrations (Cabrera \& Schulz, 2016). The nature of a given product may vary marginally, yet it is basically uniform crosswise over makers. When they are exchanged on a trade, items should likewise meet determined least benchmarks, otherwise called a premise review. An item prices is a sensibly compatible great or material, purchased and sold openly as an article of business. Commodities incorporate farming items, fills, and metals and are exchanged mass on a commodity trade or spot advertise (Frankel,2014). 
A commodity is an item for which there is request and which is provided with no unmistakable contrast in item quality or standard. A vital element of a product is that its price is resolved as an element of its market all in all - by the communication of market request and market supply (Bellemare, 2015).

- The providers to those commodity markets are the agriculturists and different makers who develop, reap or remove the item.

- The interest for items originates from the makers, wholesalers and different organizations that need to utilize the commodity in their creation forms.

Product markets are for the most part observed as extremely effective. The business sectors rapidly react to changes in free market activity to discover a harmony price and amount. That is the way price is resolved - by the connection of interest and supply (Galí \& Monacelli, 2016).

Commodities are great cases to use as an approach to consider the elements that influence the level of interest in a market. Understanding why and how commodity prices move higher or bring down is the reason for your accomplishment in exchanging products. Trust me, there are a great deal of commodity merchants out there who are endeavoring to take your cash - it's a fight amongst you and them. You must have the capacity to fuse this information into your normal research on products to benefit from those moves. Else, you might battle a losing fight. Commodity of price can be extremely unstable and it might appear as though there is no conceivable pattern to their development. I've been exchanging for over ten years and I am as yet stunned at the way prices can move. The essential clarification I can give you is that item prices move in light of free market activity issues. At whatever point the market translates there will be bring down supply, prices tend to move higher. In like manner, higher supplies by and large mean lower prices (Fiordelisi, et al.,2014).

Prices for vitality commodities - which incorporate oil, gaseous petrol, and coal - are conjecture to climb 4 percent in 2018 after a 28 percent jump this year, the World Bank said in its October Commodity Markets Outlook. The metals list is relied upon to balance out in the coming year, after a 22 percent bounce this year as a redress in press metal prices is counterbalanced by expanded prices in other base metals. Prices for horticultural commodities, including nourishment products and crude materials, are 
expected to subside humbly in 2017 and edge up one year from now. Most purchasers and merchants exchange commodities on the prospects markets in light of the fact that numerous item makers - especially those of conventional commodities like grain - bear the danger of conceivably negative value changes when their items are at long last prepared for the market. Fates contracts, whereby the purchaser buys the commitment to get a particular amount of the product at a particular date and at a particular price, subsequently offer some value strength to commodity makers and commodity clients (Chavez- Demoulin, et al.,2016). Prospects contracts are institutionalized, implying that every item has similar details for the item's quality, amount, and conveyance. This guarantees all prices mean a similar thing to everybody in the market. Raw petroleum is a case of a conventional commodity that is as often as possible exchanged utilizing fates contracts. Since every sort of raw petroleum meets a similar quality particulars, purchasers know precisely what they're getting, paying little respect to the wellspring of the oil. Be that as it may, here and there makers endeavor to mark their items with an end goal to acquire higher prices (Mizgier \& Wimmer, 2018).

\section{Operational risk}

Operational risk: "The danger of immediate or backhanded misfortune coming about because of insufficient or fizzled interior procedures, individuals and frameworks or from outside occasions (Barakat, et al.,2018)." As a first guess in creating least capital charges, the Committee gauges operational risk at $18 \%$ of least administrative capital. The Committee proposes a scope of three ways to deal with capital necessities for operational danger of expanding refinement:

- Essential pointer

- Institutionalized

- Inner estimation.

The "essential pointer approach" connects the capital charge for operational risk to a solitary marker that fills in as an intermediary for the bank's general risk presentation. For instance, if net pay is the pointer, each bank should hold capital for operational risk equivalent to a settled rate ("alpha factor") of its gross pay (Bahmani-Oskooee, et 
al.,2018). The "institutionalized approach" expands on the essential pointer approach by separating a bank's exercises into various institutionalized business lines (e.g. corporate back and retail keeping money). Inside every business line, the capital charge is a chosen marker of operational risk times a settled rate ("beta factor"). Both the pointer and the beta factor may vary crosswise over business lines.

Market risk refers to the likelihood of misfortune on ventures or exchanging tasks. There are a couple of key large scale occasions which could expand the risk to an exchanging portfolio. The most clear is the debasement in the value markets (Winkelman $\&$ Chang, 2018). Over the most recent 10 years, the value markets have encountered two considerable accidents. In March of 2000, the value markets topped which along these lines prompted a noteworthy crash in the business sectors, in particular in innovation shares. In 2007 to 2008, the value markets smashed indeed as the credit markets ended up temperamental because of the careless measure of use that people and organizations were permitted to take. These occasions bankrupted several organizations, little to extensive. In the two cases, use was the name of the diversion and bank resources and liabilities were horribly confounded (Karaman, et al.,2018). Cash was shabby and when the gathering finished, financing costs moved higher and banks imploded.

Operational risk condenses the dangers an organization embraces when it endeavors to work inside a given field or industry. Operational risk is the risk not innate in budgetary, efficient or showcase wide risk. It is the risk staying in the wake of deciding financing and deliberate risk, and incorporates dangers coming about because of breakdowns in inward techniques, individuals and frameworks (Krueger, et al.,2017).

Operational risk is "the danger of an adjustment in esteem caused by the way that real misfortunes, brought about for deficient or fizzled inside procedures, individuals and frameworks, or from outer occasions (counting lawful risk), contrast from the normal misfortunes" (Kroft \& Notowidigdo, 2016). This definition, embraced by the European association Solvency II Directive for guarantors, is a variety from that received in the Basel II controls for banks. In October 2014, the Basel Committee on Banking Supervision proposed a modification to its operational risk capital structure that sets out another institutionalized way to deal with supplant the fundamental pointer approach and the institutionalized approach for computing operational risk capital. 
Risk is the vulnerability related with the results of occasions. An operational risk occasion is regularly demonstrated by a misfortune thickness which at that point gives a model of every single conceivable result of this misfortune occasion. The greater part of operational risk misfortune information happens in nearness to the thickness focus - for the most part alluded to as the body of the dispersion which contains the normal misfortunes i.e. those misfortunes having a high likelihood of event yet with medium, or low, affect. Misfortunes happening far from the inside to the correct hand side of the thickness are ordinarily alluded to as startling misfortunes i.e. those misfortunes having a low likelihood of event however with high effect. Similarly as with different types of risk, the potential misfortune sum because of market risk might be estimated in various ways or traditions. Generally, one tradition is to utilize Value at Risk (VAR) (Hosseinpoor,2016). The traditions of utilizing Value in danger is settled and acknowledged in the transient risk administration rehearse. In any case, it contains various restricting suppositions that oblige its precision. The main suspicion is that the structure of the portfolio estimated stays unaltered over the predetermined period. Over brief time skylines, this constraining supposition is frequently viewed as sensible. Be that as it may, over longer time skylines, a significant number of the situations in the portfolio may have been changed. The Value at Risk of the unaltered portfolio is never again applicable. Moreover, mind must be taken with respect to the mediating income, inserted alternatives, and changes in drifting rate loan fees of the budgetary positions in the portfolio. They can't be overlooked if their effect can be substantial. Because of our exercises, we are presented to an assortment of dangers. Among the greatest of these dangers are credit chance, showcase chance, liquidity risk, operational risk and protection chance. Inability to control these dangers could bring about material unfavorable impacts on our money related execution and notoriety (Ellonen \& Nätti, 2015).

- Credit Risk. Credit risk is the danger of budgetary misfortune identifying with the disappointment of a borrower to respect its legally binding commitments. Credit risk emerges in loaning exercises and furthermore in different exercises where we are presented to the danger of counterparty default, for example, our exchanging, capital markets and settlement exercises. Counterparty default can 
be caused by various reasons, which we will be unable to precisely survey at the time it embraces the applicable action. Credit risk has expanded in the period since September 2007. Moreover, the database that screens defaulting clients over the saving money framework in Greece, regularly known as "Teiresias", does not screen total measures of non-defaulted credits extraordinary to an account holder. The Credit Bureau administrations of Teiresias are extending and a database for non-defaulted advances is being set up yet is as yet inadequate. Thus, the Bank is liable to the risk that its clients may have acquired unsustainably huge sums from different banks and can't affirm if and when the database will be finished.

- Market Risk. Market chance incorporates, however isn't constrained to, financing cost, outside conversion scale, security cost and value dangers. Changes in financing cost levels, yield bends and spreads may influence our net intrigue edge. Changes in cash trade rates influence the estimation of benefits and liabilities designated in remote monetary forms and may influence wage from outside trade managing. The execution of money related markets or budgetary conditions by and large may cause.

Operational risk administration is the general procedure of deliberately investigating, surveying, checking, following up and announcing whether the arranging of work undertakings is adequately strong against operational dangers (Isik, et al.,2018). Operational risk administration guarantees that Business exercises can be performed with center around quality and expert aptitudes, steadiness, proficiency, security and control. The structure compresses the arrangements and general operational prerequisites applying to bank. The system is supplemented with gritty targets and rules. The system and rules depend on worldwide principles, proposals and contributions from global participation. The system applies to all parts of banks direct of its business and to its generation surroundings, paying little respect to where the exercises are done (Eichenbaum,2017). The general operational risk administration incorporates arrangement of business exercises and readiness of appraisals of bank's operational dangers. An appropriate level of controls is resolved and executed based on the basic significance of the business action and the related risk appraisal, remembering the risk situation whenever. 


\section{Unemployment}

Unemployment is communicated as a level of the aggregate accessible work drive. The level of unemployment shifts with financial conditions and different conditions (Bahmani-Oskooee, et al.,2018). Unemployment trap is a circumstance when unemployment benefits dishearten the unemployment to go to work. Individuals discover the open door cost of going to work too high when one can essentially appreciate the advantages by doing nothing (Barakat, et al.,2018). While the reason for standardized savings and welfare frameworks is to give alleviation to the unemployment, they wind up furnishing them with a motivation not to come back to work. An unemployment trap emerges when opportunity cost of going to work is higher than the pay got, demoralizing individuals from coming back to work and being Profitability able. Unemployment is characterized by the Bureau of Labor Statistics as individuals who don't have an occupation, have effectively searched for work in the previous a month, and are as of now accessible for work (Byrne, et al.,2018). Additionally, individuals who were briefly laid off and were holding up to be gotten back to that activity are incorporated into the unemployment insights. The individuals who have not searched for work inside the previous a month are never again considered as a real part of the unemployment. The banks likewise expel them from the work drive. A great many people leave the work compel when they resign, go to class, have an inability that shields them from working, or have family duties. Indeed, even individuals who might want to work are prohibited on the off chance that they aren't currently searching for work. Here's the means by which the banks computes the Labor Force Participation Rate. The banks keep track of those individuals, however (Coibion \& Gorodnichenko, 2015). They are independently announced in the Jobs Report. The individuals, who have searched for work inside the previous a year, yet not inside the previous a month, are classified as "barely appended to the work drive." There is a subset of the hardly joined; the individuals who have recently surrendered looking since they don't think there are occupations out there for them. The banks calls them disheartened specialists, and they will presumably begin searching for work again at whatever point the activity showcase makes strides (Cabrera \& Schulz, 2016). Hence, numerous individuals feel that the bank does not report the genuine 
unemployment rate. The unemployment rate is a measure of the predominance of unemployment and it is computed as a rate by isolating the quantity of unemployment people by all people as of now in the work compel. Amid times of subsidence, an economy for the most part encounters a moderately high unemployment rate.

Unemployment happens when a man who is currently hunting down business can't look for some kind of employment. Unemployment is frequently utilized as a measure of the soundness of the economy (Ellonen \& Nätti, 2015). The most incessant measure of unemployment is the unemployment rate, which is the quantity of unemployment individuals separated by the quantity of individuals in the work compelled. On the off chance that you are not in work and would prefer not to be in work, perhaps on the grounds that you are resigned or in light of the fact that you are caring for a kid or cherished one, you don't consider unemployment. The official meaning of "unemployment" is somebody who isn't in work, has searched for work over the most recent a month and is prepared to begin work in the following two weeks. It additionally incorporates individuals who are out of work, yet have discovered a vocation and are holding up to begin it in the following two weeks (Cavalcanti, et al., 2015). This is separate to the petitioner check which measures the quantity of individuals guaranteeing benefits since they are out of work. It incorporates individuals who are on Jobseeker's Allowance and individuals guaranteeing Universal Credit, where petitioners must look for work to qualify. The legislature characterizes the individuals who need to fill in as individuals who have effectively searched for work inside the previous a month and decides the quantity of individuals as of now unemployment through a month to month study called the Current Population Survey (Horvath, et al., 2018).

Individuals can be unemployment for some reasons:

- $\quad$ They quit their position and are searching for another one.

- They were laid off because of absence of work and haven't yet been rehired.

- Their organization lessened the work power, and they are looking for another position. This can be because of a neighborhood condition, when the organization shuts a plant or division, or a national condition, when the economy moderates and numerous organizations decrease their work compel. 
- They have as of late come back to the work compel - maybe from pregnancy or going to class - and haven't yet found a position.

- The requirement for their range of abilities has gone down, and there are restricted positions accessible, which may prompt unemployment until the point when they prepare for another position.

- Technology has lessened the requirement for their kind of position.

\section{Economic growth}

Economic growth is an expansion in the limit of an economy to deliver products and ventures, contrasted from one timeframe with another (Isik, et al.,2018). It can be estimated in ostensible or genuine terms, the last of which is balanced for swelling. Customarily, total economic growth is estimated as far as gross national product (GNP) or gross domestic product (GDP), albeit elective measurements are in some cases utilized. Economic growth is an expansion in the generation of merchandise and ventures over a particular period. To be precise, the estimation must evacuate the impacts of swelling. Economic growth makes more benefit for organizations. Subsequently, stock costs rise. That gives organizations funding to contribute and procure more workers. As more occupations are made, wages rise. Shoppers have more cash to purchase extra items and administrations (Acs, et al.,2018). Economic growth can be characterized in an economy by an outward move in its Production Possibility Curve (PPC). Economic growth is estimated by the expansion in a nation's aggregate yield or genuine Gross Domestic Product (GDP) or Gross National Product (GNP). The Gross Domestic Product (GDP) of a nation is the aggregate estimation of every last great and administrations created inside a nation over some stretch of time. In this manner an expansion in GDP is the increment in a nation's creation. Development doesn't happen in separation. Occasions in a single nation and district can significantly affect development prospects in another. For instance, if there's a restriction on outsourcing work in the United States, this could massively affect India's GDP which has a vigorous IT segment reliant on outsourcing (Ogundari \& Awokuse, 2018). Increment in a nation's Profitability able limit, as estimated by looking at net national item (GNP) in a year with the GNP in the earlier year. Increment in the 
capital stock, propels in innovation, and change in the quality and level of education are thought to be the important reasons for financial development. Lately, the possibility of feasible improvement has gotten extra factors, for example, ecologically solid procedures that must be considered in growing an economy. Monetary development is the expansion in the merchandise and ventures delivered by an economy, normally a country, over a drawn out stretch of time. It is estimated as rate increment in genuine (GDP) which is (GDP) balanced for expansion (Donaldson \& Hornbeck, 2016). Gross domestic product is the market estimation of every single last great and administrations delivered in an economy or country. Therefore, all nations need positive monetary development. This makes economic growth the most viewed monetary pointer. Development is typically figured in genuine terms - i.e., expansion balanced terms - to take out the twisting impact of swelling on the cost of merchandise delivered. Estimation of economic growth utilizes national wage accounting. Since monetary development is estimated as the yearly percent change of (GDP), it has every one of the favorable circumstances and disadvantages of that measure (Moore \& Diaz, 2015). The monetary development rates of countries are generally analyzed utilizing the proportion of the GDP to populace or per-capita income. The "rate of monetary development" alludes to the geometric yearly rate of development in GDP between the first and the most recent year over some undefined time frame. Certainly, this development rate is the pattern in the normal level of GDP over the period, which verifiably disregards the vacillations in the GDP around this pattern. Monetary development is the expansion in the market estimation of the products and enterprises delivered by an economy after some time (Frankel,2014). It is customarily estimated as the percent rate of increment in genuine GDP, or genuine GDP. Of more significance is the development of the proportion of GDP to populace (GDP per capita), which is additionally called per capita salary. 


\section{Conceptual framework}

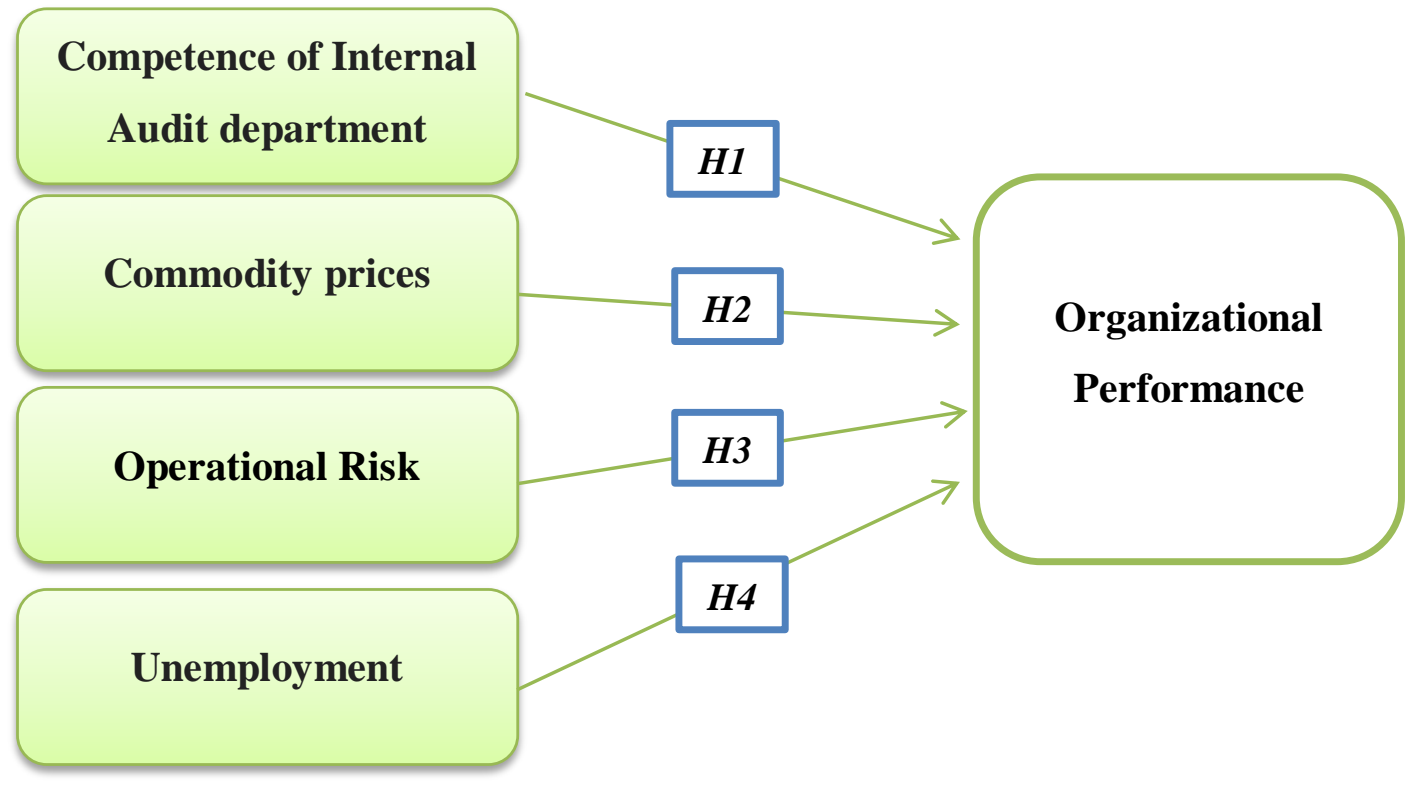

Figure 1- RESEARCH MODEL

\section{Research Hypotheses}

H1: There is a positive and significance effect of exchange rate on interest rate resulting higher banks Profitability.

H2: There is a positive and significance effect of wage inflation on interest rate resulting higher banks Profitability.

H3: There is a positive and significance effect of commodity prices on interest rate resulting higher banks Profitability.

H4: There is a positive and significance effect of operational risk on interest rate resulting higher banks Profitability.

H5: There is a positive and significance effect of unemployment on interest rate resulting higher banks Profitability.

H6: There is a positive and significance effect of economic growth on interest rate resulting higher banks Profitability. 


\section{METHODOLOGY}

The research was conducted at private banks in Erbil. The researcher attempted to find out the most of significance factor that affects interest rates and its relationship with banks Profitability. However, the researcher gathered data from employees at different level of management at private banks in Erbil. The researcher distributed 300 questionnaires, but only 238 questionnaires were received from employees and been completed. The researcher used a quantitative research method to find out the most of significance factor that affects interest rates and its relationship with banks Profitability.

\section{RESULTS}

\section{Reliability analysis}

Table -1- shows the reliability analysis employed to investigate the reliability of questions used to measure the organizational performance. Based on the research model (figure-1-), the researcher developed six research hypotheses through using exchange rate, wage inflation, commodity prices, operational risks, unemployment and economic growth as independent factors to measure banks Profitability as dependent variable. Moreover, the findings of the reliability analysis were as follow: The reliability analysis for exchange rate, the alpha was found to be .789 for 9 questions used in the analysis, the reliability analysis for wage inflation, the alpha was found to be .80 for 9 questions used in the analysis, the reliability analysis for commodity prices, the alpha was found to be .712 for 8 questions used in the analysis, the reliability analysis for operational risk, the alpha was found to be .834 for 11 questions used in the analysis, the reliability analysis for unemployment, the alpha was found to be .786 for 9 questions used in the analysis, the reliability analysis for economic growth, the alpha was found to be .739 for 10 questions used in the analysis, and the reliability analysis for wage inflation, the alpha was found to be .826 for 12 questions used in the analysis.

\section{Table 1- Reliability analysis}

\begin{tabular}{|c|c|c|c|}
\hline Variables & Cronbach's Alpha & KMO & Items \\
\hline Exchange rate & .789 & .71 & 9 \\
\hline Wage inflation & .801 & .699 & 9 \\
\hline Commodity prices & .745 & .712 & 8 \\
\hline Operational risk & .834 & .789 & 11 \\
\hline Unemployment & .786 & .709 & 9 \\
\hline
\end{tabular}




\begin{tabular}{|c|c|c|c|}
\hline Economic growth & .739 & .711 & 10 \\
\hline Banks Profitability & .826 & .776 & 12 \\
\hline
\end{tabular}

\section{Correlation Analysis}

Table -2- shows the correlation analysis, the researcher used correlation employed to find the relationship between exchange rate, wage inflation, commodity prices, operational risks, unemployment and economic growth with banks Profitability. The results of correlation analysis were as follow:

- The value of correlation between exchange rate with banks Profitability $=.685^{* *}$, as we know that $(* *)$. Correlation is significant at the 0.01 level (2-tailed), therefore it was found that there is a positive and strong correlation between exchange rate and banks Profitability.

- The value of correlation between Wage inflation with banks Profitability $=.718^{* *}$, as we know that $(* *)$. Correlation is significant at the 0.01 level (2-tailed), therefore it was found that there is a positive and strong correlation between Wage inflation and banks Profitability.

- The value of correlation between Commodity prices with banks Profitability = $.798^{* *}$, as we know that $(* *)$. Correlation is significant at the 0.01 level (2-tailed), therefore it was found that there is a positive and strong correlation between Commodity prices and banks Profitability.

- The value of correlation between Operational risk with banks Profitability = $.697^{* *}$, as we know that $(* *)$. Correlation is significant at the 0.01 level (2-tailed), therefore it was found that there is a positive and strong correlation between Operational risk and banks Profitability.

- The value of correlation between Unemployment with banks Profitability = $.714^{* *}$, as we know that $(* *)$. Correlation is significant at the 0.01 level (2-tailed),

\begin{tabular}{|l|c|c|}
\hline Factors & Correlation & $\begin{array}{c}\text { Banks } \\
\text { Profitability }\end{array}$ \\
\hline \multirow{2}{*}{ Exchange rate } & Correlation & $.685^{* *}$ \\
\cline { 2 - 3 } & Sig. (2-tailed) & .000 \\
\hline
\end{tabular}




\begin{tabular}{|l|c|c|}
\hline \multirow{4}{*}{ Wage inflation } & $\mathrm{N}$ & 209 \\
\cline { 2 - 3 } & Correlation & $.718^{* *}$ \\
\cline { 2 - 3 } & Sig. (2-tailed) & .000 \\
\hline \multirow{4}{*}{ Commodity prices } & $\mathrm{N}$ & 238 \\
\cline { 2 - 3 } & Correlation & $.798^{* *}$ \\
\cline { 2 - 3 } & Sig. (2-tailed) & .000 \\
\hline Unemployment & $\mathrm{N}$ & 238 \\
\cline { 2 - 3 } & Correlation & $.697^{* *}$ \\
\cline { 2 - 3 } & Sig. (2-tailed) & .000 \\
\hline Economic growth & $\mathrm{N}$ & 238 \\
\cline { 2 - 3 } & Correlation & $.714^{* *}$ \\
\cline { 2 - 3 } & Sig. (2-tailed) & .000 \\
\cline { 2 - 3 } & $\mathrm{N}$ & $.834^{* *}$ \\
\cline { 2 - 3 } & Correlation & .000 \\
\hline$* *$ Sig. (2-tailed) & \multicolumn{2}{|c|}{$\mathrm{N}$} \\
\hline
\end{tabular}

therefore it was found that there is a positive and strong correlation between Unemployment and banks Profitability.

- The value of correlation between Economic growth with banks Profitability = $.834^{* *}$, as we know that $(* *)$. Correlation is significant at the 0.01 level (2-tailed), therefore it was found that there is a positive and strong correlation between Economic growth and banks Profitability.

Table 2- Correlations Analysis

\section{Regression Analysis}

Table -3- shows multiple regression analysis employed to examine the research hypotheses, however, the findings revealed the followings:

- It was found the P-value between exchange rate and banks Profitability $=.000$, therefore, the first research hypothesis is supported which stated that " There is a positive and significance effect of exchange rate on interest rate resulting higher banks Profitability".

- It was found the P-value between wage inflation and banks Profitability $=.000$, therefore, the second research hypothesis is supported which stated that "There is a positive and significance effect of wage inflation on interest rate resulting higher banks Profitability". 
- It was found the P-value between commodity prices and banks Profitability = .000 , therefore, the third research hypothesis is supported which stated that ", There is a positive and significance effect of commodity prices on interest rate resulting higher banks Profitability',

- It was found the P-value between operational risk and banks Profitability $=.000$, therefore, the fourth research hypothesis is supported which stated that 'There is a positive and significance effect of operational risk on interest rate resulting higher banks Profitability'.

- It was found the P-value between unemployment and banks Profitability $=.000$, therefore, the fifth research hypothesis is supported which stated that 'There is a positive and significance effect of unemployment on interest rate resulting higher banks Profitability'.

- It was found the P-value between economic growth and banks Profitability $=.000$, therefore, the sixth research hypothesis is supported which stated that 'There is a positive and significance effect of economic growth on interest rate resulting higher banks Profitability'.

The findings of multiple regression analysis revealed that the highest value was for economic growth, the $\mathrm{B}$ value $=.812$, this indicates that economic growth significantly and positively effects interest rates as a result maximize bank's Profitability.

Table 3 Regression Analysis

\begin{tabular}{|c|c|c|c|c|c|}
\hline \multirow[t]{2}{*}{ Model } & \multicolumn{2}{|c|}{$\begin{array}{c}\text { Unstandardized } \\
\text { Coefficients }\end{array}$} & \multirow{2}{*}{$\begin{array}{c}\text { Standardized } \\
\text { Coefficients } \\
\text { Beta }\end{array}$} & \multirow[t]{2}{*}{$\mathrm{t}$} & \multirow[t]{2}{*}{ Sig. } \\
\hline & B & Std. Error & & & \\
\hline (Constant) & 1.235 & .078 & & 16.132 & .000 \\
\hline $\begin{array}{l}\text { Exchange } \\
\text { rate }\end{array}$ & .678 & .011 & .698 & 2.871 & .000 \\
\hline $\begin{array}{c}\text { Wage } \\
\text { inflation }\end{array}$ & .701 & .013 & .709 & 2.654 & .000 \\
\hline $\begin{array}{c}\text { Commodity } \\
\text { prices }\end{array}$ & .711 & .008 & .718 & 1.956 & .000 \\
\hline $\begin{array}{c}\text { Operational } \\
\text { risk }\end{array}$ & .659 & .002 & .671 & 1.789 & .000 \\
\hline $\begin{array}{c}\text { Unemployme } \\
\text { nt }\end{array}$ & .512 & .008 & .519 & 2.674 & .000 \\
\hline
\end{tabular}




\begin{tabular}{|l|c|c|c|c|c|c|}
\hline & $\begin{array}{c}\text { Economic } \\
\text { growth }\end{array}$ & .812 & .003 & .819 & 1.859 & .000 \\
\hline
\end{tabular}

\section{CONCLUSIONS}

The aim of this study is to investigate the factors influencing interest rates and its relationship with private banks profitability in Erbil. Especially, when interest rate is high, generally ascend in loaning rate is higher than the store rates which thus builds the bank spread. Be that as it may, on the opposite side when interest rates are low at that point ascending in store rate is higher than the loaning rates. As contrast with store rates, the rates of loaning are balanced all the more quickly when interest rates increment. Though when loan cost diminishes then the store rates are balanced all the more quickly as contrast with loaning rates. The assumption that the low loan cost condition break down bank benefit is somewhat affirmed by this current paper's examination. It is discovered that bank execution is to be sure disabled as an outcome of low loan fees. Additionally, the capacity of banks to produce benefits from their conventional loaning and subsidizing hones is lessened as the net premium edge is being compacted by constantly low interest rates. In any case, the banks in Erbil could keep up their general level of benefits. This could have been accomplished by adequately bringing down their level of provisioning as the default probabilities on exceptional advances are littler in a low loan cost condition.

\section{REFERENCES}

Bahmani-Oskooee, M., Chang, T., \& Ranjbar, O. (2018). Testing hysteresis effect in US state unemployment: new evidence using a nonlinear quantile unit root test. Applied Economics Letters, 25(4), 249-253.

Barakat, A., Ashby, S., \& Fenn, P. (2018). The reputational effects of analysts' stock recommendations and credit ratings: Evidence from operational risk announcements in the financial industry. International Review of Financial Analysis, 55, 1-22. 
Barsky, R., Justiniano, A., \& Melosi, L. (2014). The natural rate of interest and its usefulness for monetary policy. American Economic Review, 104(5), 37-43.

Bellemare, M. F. (2015). Rising food prices, food price volatility, and social unrest. American Journal of Agricultural Economics, 97(1), 1-21.

Byrne, J. P., Korobilis, D., \& Ribeiro, P. J. (2018). On the sources of uncertainty in exchange rate predictability. International Economic Review, 59(1), 329-357.

Cabrera, B. L., \& Schulz, F. (2016). Volatility linkages between energy and agricultural commodity prices. Energy Economics, 54, 190-203.

Cavalcanti, D. V., Tiago, V., Mohaddes, K., \& Raissi, M. (2015). Commodity price volatility and the sources of growth. Journal of Applied Econometrics, 30(6), 857873.

Chavez- Demoulin, V., Embrechts, P., \& Hofert, M. (2016). An extreme value approach for modeling operational risk losses depending on covariates. Journal of Risk and Insurance, 83(3), 735-776.

Coibion, O., \& Gorodnichenko, Y. (2015). Is the Phillips curve alive and well after all? Inflation expectations and the missing disinflation. American Economic Journal: Macroeconomics, 7(1), 197-232.

Délèze, F., \& Korkeamäki, T. (2018). Interest rate risk management with debt issues: Evidence from Europe. Journal of Financial Stability, 36, 1-11.

Donayre, L., \& Panovska, I. (2018). US wage growth and nonlinearities: The roles of inflation and unemployment. Economic Modelling, 68, 273-292.

Eichenbaum, M. (2017). Discussion of 'The Role of the Growth of Risk-Averse Wealth in the Decline of the Safe Real Interest Rate'by Bob Hall.

Enders, A., Enders, Z., \& Hoffmann, M. (2018). International financial market integration, asset compositions, and the falling exchange rate pass-through. Journal of International Economics, 110, 151-175.

Fiordelisi, F., Soana, M. G., \& Schwizer, P. (2014). Reputational losses and operational risk in banking. The European Journal of Finance, 20(2), 105-124.

Frankel, J. A. (2014). Effects of speculation and interest rates in a "carry trade" model of commodity prices. Journal of International Money and Finance, 42, 88-112. 
Fukuda, S. I. (2018). Impacts of Japan's negative interest rate policy on Asian financial markets. Pacific Economic Review, 23(1), 67-79.

Galí, J., \& Monacelli, T. (2016). Understanding the gains from wage flexibility: the exchange rate connection. American Economic Review, 106(12), 3829-68.

Höpner, M., \& Lutter, M. (2018). The diversity of wage regimes: Why the Eurozone is too heterogeneous for the euro. European Political Science Review, 10(1), 71-96.

Horvath, R., Kotlebova, J., \& Siranova, M. (2018). Interest rate pass-through in the euro area: Financial fragmentation, balance sheet policies and negative rates. Journal of Financial Stability, 36, 12-21.

Hosseinpoor, A. (2016). The effect of government size on unemployment rate in Iran. The Economic Research, 16 (1), 191-209.

Huang, Y., Mao, K., Chen, X., Sun, M. A., Kawabe, T., Li, W., .. \& Germain, R. N. (2018). S1P-dependent interorgan trafficking of group 2 innate lymphoid cells supports host defense. Science, 359(6371), 114-119.

Jagannathan, R. (2018). A Linear Regression Approach for Determining Option Pricing for Currency-Rate Diffusion Model with Dependent Stochastic Volatility, Stochastic Interest Rate, and Return Processes. Journal of Mathematical Finance, 8(01), 161.

Karaman Örsal, D. D., \& Goldstein, J. R. (2018). The changing relationship between unemployment and total fertility. Population studies, 72(1), 109-121.

Kroft, K., \& Notowidigdo, M. J. (2016). Should unemployment insurance vary with the unemployment rate? Theory and evidence. The Review of Economic Studies, 83(3), 1092-1124.

Krueger, A. B., Mas, A., \& Niu, X. (2017). The Evolution of Rotation Group Bias: Will the Real Unemployment Rate Please Stand Up?. Review of Economics and Statistics, 99(2), 258-264.

Kuttner, K. N., \& Shim, I. (2016). Can non-interest rate policies stabilize housing markets? Evidence from a panel of 57 economies. Journal of Financial Stability, 26, 31-44.

Laubach, T., \& Williams, J. C. (2016). Measuring the natural rate of interest redux. Business Economics, 51(2), 57-67. 
Mizgier, K. J., \& Wimmer, M. (2018). Incorporating single and multiple losses in operational risk: a multi-period perspective. Journal of the Operational Research Society, 1-14.

Murphy, R. G., \& Rohde, A. (2018). Rational Bias in Inflation Expectations. Eastern Economic Journal, 44(1), 153-171.

Nguyen, C. V. (2018). The Mexican Interest Rate Pass-Through in the Post-US Subprime Mortgage Crisis Era. The International Trade Journal, 32(1), 100-115.

Nucci, F., \& Riggi, M. (2018). Labor force participation, wage rigidities, and inflation. Journal of Macroeconomics, 55, 274-292.

Pan, J., \& Zhou, X. (2017). Pricing for options in a mixed fractional Hull-White interest rate model. International Journal of Financial Engineering, 4(01), 1750011.

Perera, P. R. M. R., Silva, N. L. C., \& Silva, N. L. (2018). The Impact of Interest Rate in Determining Exchange Rate: Revisiting Interest Rate Parity Theory. Journal for Accounting Researchers and Educators (JARE), 1(1).

Perera, P. R. M. R., Silva, N. L. C., \& Silva, N. L. (2018). The Impact of Interest Rate in Determining Exchange Rate: Revisiting Interest Rate Parity Theory. Journal for Accounting Researchers and Educators (JARE), 1(1).

Sun, Y., Yao, K., \& Fu, Z. (2018). Interest rate model in uncertain environment based on exponential Ornstein-Uhlenbeck equation. Soft Computing, 22(2), 465-475.

Vines, D., \& Wills, S. (2018). The financial system and the natural real interest rate: towards a 'new benchmark theory model'. Oxford Review of Economic Policy, 34(1-2), 252-268.

Winkelman, T. N., \& Chang, V. W. (2018). Medicaid expansion, mental health, and access to care among childless adults with and without chronic conditions. Journal of general internal medicine, 33(3), 376-383.

Wynne, M. A., \& Zhang, R. (2018). Measuring the World Natural Rate of Interest. Economic Inquiry, 56(1), 530-544.

Ellonen, N., \& Nätti, J. (2015). Job insecurity and the unemployment rate: Micro-and macro-level predictors of perceived job insecurity among Finnish employees 1984-2008. Economic and Industrial Democracy, 36(1), 51-71. 
Isik, C., Dogru, T., \& Turk, E. S. (2018). A nexus of linear and non- linear relationships between tourism demand, renewable energy consumption, and economic growth: Theory and evidence. International Journal of Tourism Research, 20(1), 38-49.

Acs, Z. J., Estrin, S., Mickiewicz, T., \& Szerb, L. (2018). Entrepreneurship, institutional economics, and economic growth: an ecosystem perspective. Small Business Economics, 1-14.

Ogundari, K., \& Awokuse, T. (2018). Human capital contribution to economic growth in Sub-Saharan Africa: Does health status matter more than education?. Economic Analysis and Policy, 58, 131-140.

Donaldson, D., \& Hornbeck, R. (2016). Railroads and American economic growth: A “market access" approach. The Quarterly Journal of Economics, 131(2), 799-858.

Moore, F. C., \& Diaz, D. B. (2015). Temperature impacts on economic growth warrant stringent mitigation policy. Nature Climate Change, 5(2), 127. 